Journal of Applied Pharmaceutical Science Vol. 5 (09), pp. 127-130, September, 2015

Available online at http://www.japsonline.com

DOI: $10.7324 / \mathrm{JAPS} .2015 .50924$

ISSN 2231-3354 (cc)) BY-NC-SA

\title{
Analgesic and antihyperglycemic activity evaluation of Bambusa vulgaris aerial parts
}

\author{
A. K. M. Mahmudul Haque ${ }^{1}$, Anuj Kumer Das ${ }^{1}$, Shamrat Shafiul Bashar ${ }^{1}$, Rahat Al-Mahamud ${ }^{1}$, Mohammed \\ Rahmatullah $^{2} *$ \\ ${ }^{1}$ Department of Biotechnology \& Genetic Engineering, University of Development Alternative, Dhanmondi, Dhaka-1209, Bangladesh. \\ ${ }^{2}$ Department of Pharmacy, University of Development Alternative, Lalmatia, Dhaka-1207, Bangladesh.
}

\begin{tabular}{l} 
ARTICLE INFO \\
\hline Article history: \\
Received on: $06 / 07 / 2015$ \\
Revised on: $14 / 08 / 2015$ \\
Accepted on: 04/09/2015 \\
Available online: $27 / 09 / 2015$ \\
\hline Key words: \\
Analgesic, Bambusa \\
vulgaris, antihyperglycemic, \\
Poaceae
\end{tabular}

\begin{abstract}
Bambusa vulgaris, also known as 'Ora Bansh' in Bangladesh is grown throughout the country for housing and scaffolding purposes. As part of our analgesic and antihyperglycemic plants of Bangladesh screening program, it was of interest to evaluate the analgesic and antihyperglycemic potential of aerial parts of the plant. Methanolic extract of aerial parts (MEBV) at doses of 50, 100, 200 and $400 \mathrm{mg}$ per $\mathrm{kg}$ significantly reduced the number of writhings in acetic acid-induced pain model Swiss albino mice by $25.9,29.6,37.0$, and $44.4 \%$, respectively compared to reductions of 40.7 and $51.9 \%$, respectively, obtained with 200 and $400 \mathrm{mg}$ per $\mathrm{kg}$ of a standard analgesic drug, aspirin. MEBV, at doses of 100, 200 and $400 \mathrm{mg}$ per $\mathrm{kg}$ also significantly lowered blood glucose levels in mice, respectively, by $32.8,45.8$, and $55.3 \%$ compared to control mice. A standard antihyperglycemic drug, glibenclamide, when administered at a dose of $10 \mathrm{mg}$ per $\mathrm{kg}$ lowered blood glucose level by $50.8 \%$. Taken together, the results indicate that the aerial parts of the plant possess considerable analgesic and antihyperglycemic potential, which can possibly be attributed to the presence of alkaloids and saponins in the extract.
\end{abstract}

\section{INTRODUCTION}

Bambusa vulgaris Schrad. ex J.C. Wendl. (Poaceae), known in English as Golden Bamboo and Ora Bansh in Bengali is an open clump-type bamboo species and is grown in Bangladesh primarily for construction and scaffolding purposes. The plant has ethnomedicinal uses in several parts of the world. In Trinidad and Tobago, the plant is used for cuts, injuries and swellings (Lans, 2007). The leaves are used in Ogun State, Nigeria for treatment of typhoid fever (Fadimu et al., 2014). The plant is used to treat gonorrhea in Ethiope Council Area of Delta State, Nigeria (Idu and Ndukwu, 2006). It is used for treatment of malaria in the Dangme West District of Ghana (Asase et al., 2010). Aqueous extract of the plant grown in Sri Lanka has been reported to significantly lower the fasting blood glucose level and markedly improve glucose tolerance in Sprague-Dawley rats (Fernando et al., 1990). In vitro antimalarial activity against Plasmodium falciparum Ghana strain has been seen with

* Corresponding Author

Email: rahmatm@uoda.edu.bd hydroalcoholic extract of the plant (Valdés et al., 2010). Extract of the plant also showed promising activity against the amastigote stage of Leishmania amazonensis (García et al., 2012). We had been conducting an extensive pharmacological screening of medicinal plants of Bangladesh with analgesic and antihyperglycemic potential (Morshed et al., 2010; Rahmatullah et al., 2010; Ahmed et al., 2011; Shahreen et al., 2012; Haque et al., 2013; Rahmatullah et al., 2013a,b; Ghosh et al., 2014; Hossain et al., 2014; Jahan et al., 2014; Rahman et al., 2014; Tazin et al., 2014). Diabetes and pain are common afflictions within not only Bangladesh but also throughout the world. The rural people who lack adequate infrastructure in the form of easy communications and modern medical facilities often suffer due to lack of access to quality health-care centers and modern medicines. As such, analgesic and antihyperglycemic plants can form an easily accessible and affordable source for such analgesic and antihyperglycemic drugs in the crude form provided such plants have been validated by scientific research to have the relevant pharmacological activities and are non-toxic. The objective of the present study was to evaluate the analgesic and antihyperglycemic potential of $B$. vulgaris, which is readily available in the rural 


\section{MATERIALS AND METHODS}

\section{Plant material collection}

Aerial parts of B. vulgaris were collected during June 2014 from Dhaka, Bangladesh and taxonomically identified at the Bangladesh National Herbarium (Accession Number 39,565).

\section{Preparation of methanolic extract of aerial parts}

Aerial parts were cut into small pieces, air-dried in the shade, and $100 \mathrm{~g}$ of dried and powdered aerial parts were extracted with methanol (w:v ratio of 1:6, final weight of the extract $2.213 \mathrm{~g})$.

\section{Chemicals and Drugs}

Glibenclamide, aspirin, and glucose were obtained from Square Pharmaceuticals Ltd., Bangladesh. All other chemicals were of analytical grade.

\section{Animals}

Swiss albino mice, which weighed between $12-16 \mathrm{~g}$ were used in the present study. The animals were obtained from International Centre for Diarrhoeal Disease Research, Bangladesh (ICDDR,B). The animals were acclimatized for three days prior to actual experiments. The study was conducted following approval by the Institutional Animal Ethical Committee of University of Development Alternative, Dhaka, Bangladesh.

\section{Analgesic activity evaluation through abdominal writhing test}

Analgesic activity of methanolic extract of aerial parts (MEBV) was examined as previously described (Shanmugasundaram and Venkataraman, 2005). Mice were divided into seven groups of five mice each. Group 1 served as control and was administered vehicle only. Groups 2 and 3 were orally administered the standard analgesic drug aspirin at doses of 200 and $400 \mathrm{mg}$ per $\mathrm{kg}$ body weight, respectively. Groups 4-7 were administered MEBV at doses of 50, 100, 200 and $400 \mathrm{mg}$ per $\mathrm{kg}$ body weight, respectively.

Following a period of 60 minutes after oral administration of standard drug or MEBV, all mice were intraperitoneally injected with $1 \%$ acetic acid at a dose of $10 \mathrm{ml}$ per $\mathrm{kg}$ body weight. A period of 5 minutes was given to each animal to ensure bioavailability and onset of chemically induced irritation of acetic acid (Akter et al., 2014), following which period, the number of abdominal constrictions (writhings) was counted for $10 \mathrm{~min}$. The percent inhibitions of abdominal constrictions were calculated according to the formula given below;

\section{Percent inhibition $=\left(1-\mathrm{W}_{\mathrm{e}} / \mathrm{W}_{\mathrm{c}}\right) \times 100$}

where $\mathrm{W}_{\mathrm{e}}$ and $\mathrm{W}_{\mathrm{c}}$ represents the number of writhings in aspirin or MEBV administered mice (Groups 2-7), and control mice (Group 1), respectively.

\section{Oral glucose tolerance tests for evaluation of antihyperglycemic activity}

Oral glucose tolerance tests (OGTT) were carried out as per the procedure previously described by Joy and Kuttan (1999) with minor modifications. Briefly, fasted mice were grouped into six groups of five mice each. The various groups received different treatments like Group 1 received vehicle (1\% Tween 80 in water, $10 \mathrm{ml} / \mathrm{kg}$ body weight) and served as control, Group 2 received standard drug (glibenclamide, $10 \mathrm{mg} / \mathrm{kg}$ body weight). Groups 3-6 received methanolic aerial part extract (MEBV) at doses of 50, 100, 200 and $400 \mathrm{mg}$ per $\mathrm{kg}$ body weight. All substances were orally administered.

Following a period of one hour, all mice were orally administered $2 \mathrm{~g}$ glucose $/ \mathrm{kg}$ of body weight. Blood samples were collected 120 minutes after the glucose administration through puncturing heart. Blood glucose levels were measured by glucose oxidase method (Venkatesh et al., 2004). The percent lowering of blood glucose levels were calculated according to the formula described below.

Percent lowering of blood glucose level $=\left(1-\mathrm{W}_{\mathrm{e}} / \mathrm{W}_{\mathrm{c}}\right) \mathrm{X} 100$, where $\mathrm{W}_{\mathrm{e}}$ and $\mathrm{W}_{\mathrm{c}}$ represents the blood glucose concentration in glibenclamide or MEBV administered mice (Groups 2-6), and control mice (Group 1), respectively.

\section{Acute toxicity test}

Acute toxicity test was conducted as previously described (Ganapaty et al., 2002). Mice were divided into nine groups, each group consisting of six animals. Group 1 was given $1 \%$ Tween 80 in normal saline ( $2 \mathrm{ml}$ per $\mathrm{kg}$ body weight). The other eight groups (Groups 2-9) were administered, respectively, 100, 200, 300, 600, 800, 1000, 2000 and $3000 \mathrm{mg}$ of MEBV per $\mathrm{kg}$ body weight. All animals were closely observed for the next 8 hours to notice any behavioral changes or mortality and were kept under close observation for the next two weeks.

\section{Statistical analysis}

Experimental values are expressed as mean \pm SEM. Independent Sample t-test was carried out for statistical comparison. Statistical significance was considered to be indicated by a p value $<0.05$ in all cases (Hossain et al., 2014).

\section{Preliminary phytochemical screening}

Preliminary phytochemical analysis of MEBV for presence of saponins, tannins, alkaloids, and flavonoids were conducted as described before (Kumar et al., 2013).

\section{RESULTS AND DISCUSSION}

\section{Toxicity evaluation}

The crude extract (MEBV) did not show any toxicity in mice even at the highest dose tested. There were no changes in behavioral pattern and mortality was not observed. 


\section{Preliminary screening of phytochemicals}

Various tests conducted for presence of phytochemicals in MEBV indicated the presence of alkaloids and saponins.

\section{Analgesic activity evaluation results}

MEBV exhibited dose-dependent and significant analgesic activity in acetic acid-induced writhing tests. At doses of 50, 100, 200 and $400 \mathrm{mg}$ per $\mathrm{kg}$, administration of MEBV led to respectively, 25.9, 29.6, 37.0, and $44.4 \%$ reductions in the number of writhings in experimental mice compared to control animals. A standard analgesic drug, aspirin, when administered to mice at doses of 200 and $400 \mathrm{mg}$ per $\mathrm{kg}$, led to, respectively, 40.7 and $51.9 \%$ reductions in the number of writhings. Thus, at the highest dose of $400 \mathrm{mg}$ per $\mathrm{kg}$, MEBV administration showed better analgesic activity than $200 \mathrm{mg}$ aspirin per $\mathrm{kg}$. The results are shown in Table 1 and suggest that the methanolic crude extract of MEBV can be used for analgesic purposes.

Table 1: Analgesic effect of crude methanol extract of $B$. vulgaris aerial parts $(\mathrm{MEBV})$ in acetic acid-induced pain model mice.

\begin{tabular}{lccc}
\hline Treatment & $\begin{array}{c}\text { Dose (mg/kg } \\
\text { body weight) }\end{array}$ & $\begin{array}{c}\text { Mean number of } \\
\text { abdominal } \\
\text { constrictions }\end{array}$ & \% inhibition \\
\hline Control & $10 \mathrm{ml}$ & $5.4 \pm 0.24$ & - \\
Aspirin & $200 \mathrm{mg}$ & $3.2 \pm 0.58$ & $40.7^{*}$ \\
Aspirin & $400 \mathrm{mg}$ & $2.6 \pm 0.40$ & $51.9^{*}$ \\
(MEBV) & $50 \mathrm{mg}$ & $4.0 \pm 0.32$ & $25.9^{*}$ \\
(MEBV) & $100 \mathrm{mg}$ & $3.8 \pm 0.37$ & $29.6^{*}$ \\
(MEBV) & $200 \mathrm{mg}$ & $3.4 \pm 0.24$ & $37.0^{*}$ \\
(MEBV) & $400 \mathrm{mg}$ & $3.0 \pm 0.32$ & $44.4^{*}$ \\
\hline
\end{tabular}

All administrations (aspirin and extract) were made orally. Values represented as mean \pm SEM, $(\mathrm{n}=5)$; ${ }^{*} P<0.05$; significant compared to control.

\section{Antihyperglycemic activity evaluation results}

In oral glucose tolerance tests, MEBV when administered at doses of 50, 100, 200 and $400 \mathrm{mg}$ per kg body weight, dosedependently reduced the amount of blood glucose in experimental animals. At these four doses, MEBV, respectively, decreased blood glucose levels by $8.4,32.8,45.8$, and $55.3 \%$. However, the results at the dose of $50 \mathrm{mg}$ MEBV per $\mathrm{kg}$ were not statistically significant. A standard antihyperglycemic drug, glibenclamide when administered at a dose of $10 \mathrm{mg}$ per $\mathrm{kg}$ body weight, reduced blood glucose levels by $50.8 \%$. Thus MEBV at the highest dose tested showed better antihyperglycemic activity than glibenclamide. The results are shown in Table 2 and suggest that MEBV can be used to reduce blood glucose levels in hyperglycemic subjects. Presence of alkaloids and saponins in MEBV can be responsible for the observed analgesic and antihyperglycemic effects. The analgesic activity of methanolic extract of Microcos paniculata barks and fruits has been attributed to presence of alkaloids, saponins, tannins, flavonoids and triterpenoids (Aziz, 2015). Analgesic activity of methanolic leaf extract of Dalbergia saxatilis has been reported in rat and mice models. The extract was found to contain a mixture of alkaloids, flavonoids, tannins, saponins, cardiac glycosides, and triterpenes (Hassan et al., 2015). Root bark extract of Xeromphis nilotica also reportedly showed analgesic and anti-inflammatory efficacy using in vivo models of pain and inflammation in mice and rats. Important bioactive constituents present in the extract included coumarin, alkaloids, flavonoids, saponins, and terpenes (Adzu et al., 2014). The antinociceptive activity of ethanolic extract of Curcuma zedoaria rhizome has also been attributed to presence of tannins, saponins, flavonoids, gums \& carbohydrates, steroids, alkaloids, reducing sugars and terpenoids in the extract (Ullah et al., 2014).

Table 2: Effect of crude methanol extract of B. vulgaris aerial parts (MEBV) on blood glucose level in hyperglycemic mice following 120 minutes of glucose loading.

\begin{tabular}{lccc}
\hline Treatment & $\begin{array}{c}\text { Dose (mg/kg } \\
\text { body weight) }\end{array}$ & $\begin{array}{c}\text { Blood glucose } \\
\text { level (mmol/l) }\end{array}$ & $\begin{array}{c}\text { \% lowering of } \\
\text { blood glucose } \\
\text { level }\end{array}$ \\
\hline Control & $10 \mathrm{ml}$ & $5.24 \pm 0.22$ & - \\
Glibenclamide & $10 \mathrm{mg}$ & $2.58 \pm 0.21$ & $50.8^{*}$ \\
(MEBV) & $50 \mathrm{mg}$ & $4.80 \pm 0.43$ & 8.4 \\
(MEBV) & $100 \mathrm{mg}$ & $3.52 \pm 0.31$ & $32.8^{*}$ \\
(MEBV) & $200 \mathrm{mg}$ & $2.84 \pm 0.17$ & $45.8^{*}$ \\
(MEBV) & $400 \mathrm{mg}$ & $2.34 \pm 0.21$ & $55.3^{*}$ \\
\hline
\end{tabular}

All administrations were made orally. Values represented as mean \pm SEM, $(\mathrm{n}=5) ;{ }^{*} P<0.05$; significant compared to hyperglycemic control animals.

Antidiabetic and antihyperlipidemic effects of an ethanolic extract of the whole plant of Tridax procumbens has been observed in streptozotocin-induced diabetic rats. Preliminary phytochemical analysis of the extract showed presence of alkaloids, tannins, flavonoids, saponins, and phenolic compounds (Petchi et al., 2013).

Antihyperglycemic activity of the stem-bark extract of Tamarindus indica has been observed in experimentally induced hyperglycaemic and normoglycaemic Wistar rats. Phytochemical screening revealed the presence of carbohydrates, glycosides, saponins, flavonoids, cardiac glycosides, tannins, alkaloids and triterpenes (Yerima et al., 2014). The exact nature of the bioactive component(s) responsible for the observed analgesic and antihyperglycemic effects is currently being undertaken in our laboratory.

\section{CONCLUSION}

The results suggest that methanolic extract of $B$. vulgaris aerial parts can be used for lowering of blood glucose and for alleviating pain.

\section{ACKNOWLEDGEMENTS}

The authors thank Shahnaz Rahman and Erena Islam for their help in the experiments. The authors also declare that they have no conflicts of interest.

\section{REFERENCES}

Adzu B, Amizan MB, Okhale SE. Evaluation of antinociceptive and anti-inflammatory activities of standardized rootbark extract of Xeromphis nilotica. J Ethnopharmacol, 2014; 158 Pt A:271-275.

Ahmed F, Rahman S, Ahmed N, Hossain M, Biswas A, Sarkar S, Banna H, Khatun MA, Chowdhury MH, Rahmatullah M. Evaluation of Neolamarckia cadamba (Roxb.) Bosser leaf extract on glucose tolerance 
in glucose-induced hyhperglycemic mice. Afr J Trad Complement Altern Med, 2011; 8:79-81.

Akter M, Mitu IZ, Proma JJ, Rahman SM, Islam MR, Rahman S, Rahmatullah M. Antihyperglycemic and antinociceptive activity evaluation of methanolic extract of Trichosanthes anguina fruits in Swiss albino mice. Adv Nat Appl Sci, 2014; 8:70-74.

Asase A, Akwetey GA, Achel DG. Ethnopharmacological use of herbal remedies for the treatment of malaria in the Dangme West District of Ghana. J Ethnopharmacol, 2010; 129:367-376.

Aziz MA. Qualitative phytochemical screening and evaluation of anti-inflammatory, analgesic and antipyretic activities of Microcos paniculata barks and fruits. J Integr Med, 2015; 13:173-184.

Fadimu, Yomi O, Mohammed I, Zurmi SR. Ethnomedicinal survey of anti-typhoid plants in Ijebu Ode Local Government Area of Ogun State, Nigeria. Int J Science Nature, 2014; 5:332-336.

Fernando MR, Thabrew MI, Karunanayake EH. Hypoglycaemic activity of some medicinal plants in Sri-Lanka. Gen Pharmacol, 1990; 21:779-782.

Ganapaty S, Dash GK, Subburaju T, Suresh P. Diuretic, laxative and toxicity studies of Cocculus hirsutus aerial parts. Fitoterapia, 2002; 73:28-31.

García M, Monzote L, Scull R, Herrera P. Activity of Cuban Plants Extracts against Leishmania amazonensis. ISRN Pharmacol, 2012; 2012:104540. doi: 10.5402/2012/104540.

Ghosh D, Mandal I, Rumi JF, Trisha UK, Jannat H, Ahmed M, Rahmatullah M. Effect of Allium sativum leaf extracts on glucose tolerance in glucose-induced htperglycemic mice. Adv Nat Appl Sci, 2014; 8:66-69.

Hassan FI, Zezi AU, Yaro AH, Danmalam UH. Analgesic, antiinflammatory and antipyretic activities of the methanol leaf extract of Dalbergia saxatilis Hook.F in rats and mice. J Ethnopharmacol, 2015; 166:74-78

Haque ME, Rahman S, Rahmatullah M, Jahan R. Evaluation of antihyperglycemic and antinociceptive activity of Xanthium indicum stem extract in Swiss albino mice. BMC Complement Alternat Med, 2013; 13:296-299.

Hossain AI, Faisal M, Rahman S, Jahan R, Rahmatullah M. A preliminary evaluation of antihyperglycemic and analgesic activity of Alternanthera sessilis aerial parts. BMC Complement Alternat Med, 2014; 14:169-173.

Idu M, Ndukwu BC. Studies of 'plants used in ethnomedicine in Ethiope Council Area of Delta State, Nigeria. Res J Bot, 2006; 1:30-43.

Jahan S, Rahmatullah M. Methanolic extract of aerial parts of Raphanus sativus var. hortensis shows antihyperglycemic and antinociceptive potential. World J Pharm Pharmaceut Sci, 2014; 3:193202.

Joy KL, Kuttan RJ. Anti-diabetic activity of Picrorrhiza kurroa extract. J Ethnopharmacol, 1999; 67:143-148.

Kumar C, Kumar R, Nehar S. Phytochemical properties, total antioxidant status of acetone and methanol extract of Terminalia arjuna Roxb. bark and its hypoglycemic effect on Type-II diabetic albino rats. J Pharmacogn Phytochem, 2013; 2:199-208.

Lans C. Comparison of plants used for skin and stomach problems in Trinidad and Tobago with Asian ethnomedicine. J Ethnobiol Ethnomed, 2007; 3:3-14.

Morshed A, Hossain MH, Shakil S, Nahar K, Rahman S, Ferdausi D, Hossain T, Ahmad I, Chowdhury MH, Rahmatullah M. Evaluation of antinociceptive activity of two Bangladeshi medicinal plants, Kalanchoe pinnata (Lam.) Pers. and Lagerstroemia speciosa (L.) Pers. Adv Nat Appl Sci, 2010; 4:193-197.
Petchi RR, Parasuraman S, Vijaya C. Antidiabetic and antihyperlipidemic effects of an ethanolic extract of the whole plant of Tridax procumbens (Linn.) in streptozotocin-induced diabetic rats. J Basic Clin Pharm, 2013; 4:88-92.

Rahman S, Jahan R, Rahmatullah M. Effect of paddy husk extracts on glucose tolerance in glucose-induced hyperglycemic mice. World J Pharm Pharmaceut Sci, 2014; 3:111-120.

Rahmatullah M, Sultan S, Toma TT, Lucky SS, Chowdhury MH, Haque WM, Annay MEA, Jahan R. Effect of Cuscuta reflexa stem and Calotropis procera leaf extracts on glucose tolerance in glucoseinduced hyperglycemic rats and mice. Afr J Trad Complement Altern Med, 2010; 7:109-112.

Rahmatullah M, Hosain M, Rahman S, Rahman S, Akter M, Rahman F, Rehana F, Munmun M, Kalpana MA. Antihyperglycaemic and antinociceptive activity evaluation of methanolic extract of whole plant of Amaranthus tricolour L. (Amaranthaceae). Afr J Trad Complement Altern Med, 2013a; 10:408-411.

Rahmatullah M, Hossain M, Mahmud A, Sultana N, Rahman SM, Islam MR, Khatoon MS, Jahan S, Islam F. Antihyperglycemic and antinociceptive activity evaluation of 'khoyer' prepared from boiling the wood of Acacia catechu in water. Afr J Trad Complement Altern Med, $2013 b ; 10: 1-5$

Shahreen S, Banik J, Hafiz A, Rahman S, Zaman AT, Shoyeb MA, Chowdhury MH, Rahmatullah M. Antihyperglycemic activities of leaves of three edible fruit plants (Averrhoa carambola, Ficus hispida and Syzygium samarangense) of Bangladesh. Afr J Trad Complement Altern Med, 2012; 9:287-291.

Shanmugasundaram P, Venkataraman S. Anti-nociceptive activity of Hygrophilous auriculata (Schum) Heine. Afr J Tradit Complement Altern Med, 2005; 2:62-69.

Tazin TQ, Rumi JF, Rahman S, Al-Nahain A, Jahan R, Rahmatullah M. Oral glucose tolerance and antinociceptive activity evaluation of methanolic extract of Vigna unguiculata ssp. unguiculata beans. World J Pharm Pharmaceut Sci, 2014; 3:28-37.

Ullah HM, Zaman S, Juhara F, Akter L, Tareq SM, Masum EH, Bhattacharjee R. Evaluation of antinociceptive, in-vivo \& in-vitro antiinflammatory activity of ethanolic extract of Curcuma zedoaria rhizome. BMC Complement Altern Med, 2014; 14:346. doi: 10.1186/1472-688214-346.

Valdés AF, Martínez JM, Lizama RS, Gaitén YG, Rodríguez DA, Payrol JA. In vitro antimalarial activity and cytotoxicity of some selected Cuban medicinal plants. Rev Inst Med Trop Sao Paulo, 2010; 52:197-201.

Venkatesh S, Reddy GD, Reddy YSR, Sathyavathy D, Reddy B. Effect of Helicteres isora root extracts on glucose tolerance in glucoseinduced hyperglycemic rats. Fitoterapia, 2004; 75:364-367.

Yerima M, Anuka JA, Salawu OA, Abdu-Aguye I. Antihyperglycaemic activity of the stem-bark extract of Tamarindus indica L. on experimentally induced hyperglycaemic and normoglycaemic Wistar rats. Pak J Biol Sci, 2014; 17:414-418.

\section{How to cite this article:}

University of Development Alternative, Dhaka, Bangladesh., Analgesic and antihyperglycemic activity evaluation of Bambusa vulgaris aerial parts. J App Pharm Sci, 2015; 5 (09): 127-130. 